\title{
Penerapan Teknik Probing dalam Model Pembelajaran Kooperatif untuk Meningkatkan Hasil Belajar Matematika Siswa
}

\author{
Rezki Amaliyah, AR \\ Program Studi Pendidikan Matematika FMIPA Universitas Sulawesi Barat \\ e-mail: rezkiamaliyah@gmail.com
}

\begin{abstract}
Abstrak
Penelitian ini adalah penelitian Tindakan Kelas (Classroom Action Research) yang bertujuan untuk mengupayakan terjadinya peningkatan hasil belajar matematika siswa melalui penerapan teknik probing dalam model pembelajaran kooperatif. Subjek penelitian ini adalah siswa SMP Negeri 26 Makassar. Penelitian berlangsung selama dua siklus dengan tahap perencanaan,pelaksanaan tindakan,observasi/evaluasi dan refleksi. Pengambilan data dilaksanakan dengan menggunakan tes hasil belajar dan observasi kemudian dianalisis secara kualitatif dan kuantitatif. Hasil penelitian menunjukkan bahwa pada siklus I persentase siswa yang hasil belajarnya mencapai KKM adalah 78,95\% dengan mean 71,79. Sedangkan pada siklus II adalah 94,74\% dengan mean 79,39. Hal ini memperlihatkan bahwa terjadi peningkatan hasil belajar siswa selama proses pembelajaran berlangsung setelah diterapkan teknik probing model pembelajaran kooperatif. Hasil observasi menunjukkan adanya perubahan sikap siswa antara lain siswa menjadi lebih aktif dalam proses belajar, motivasi siswa untuk belajar meningkat sehingga semangat siswa mengalami peningkatan dalam menyelesaikan tugas yang diberikan, siswa berani bertanya materi pelajaran yang belum dimengerti dan menjawab pertanyaan guru, mengeluarkan pendapat/menanggapi penjelasan guru atau temannya, mampu menyimpulkan materi yang diajarkan. Hal ini menunjukkan bahwa semangat, keberanian dan rasa percaya diri siswa mengalami peningkatan selama proses pembelajaran berlangsung selama diterapkan teknik probing dalam model pembelajaran kooperatif. Oleh sebab itu, diharapkan kepada guru, khususnya guru matematika agar dapat menerapkan teknik probing dalam proses pembelajaran.
\end{abstract}

Kata kunci: Hasil Belajar Matematika, Pembelajaran Kooperatif, Teknik Probing.

\section{PENDAHULUAN}

Salah satu mata pelajaran yang dianggap penting dalam mencapai tujuan pendidikan dan ilmu pengetahuan dan teknologi (IPTEK) adalah pelajaran matematika yang merupakan sarana berfikir logis, analisis dan sistematis. Sehingga ilmu pengetahuan dan teknologi atas landasan dan kerangka berfikir matematika dan bahkan matematika merupakan sarana pembentukan intelektual. Menyadari pentinganya pelajaran matematika dalam perkembangan pengetahuan dan teknologi, maka siswa dituntut untuk menguasainya karena juga merupakan landasan yang kuat untuk melanjutkan pendidikan kejenjang yang lebih tinggi. Salah satu cara yang ditempuh dalam meningkatkan mutu pendidikan matematika adalah kondisi pembelajaran matematika. Perbaikan tersebut mencakup peningkatan mutu materi pengajaran dan pengetahuan proses pembelajaran. Hal ini sangat dipandang penting karena kegiatan pembelajaran merupakan kegiatan yang paling utama dalam pendidikan. Dalam kegiatan pembelajaran, siswa secara formal dan diarahkan sesuai dengan tujuan yang diinginkan. Baik itu untuk meningkatkan hasil belajar mereka maupun perubahan tingkah laku mereka. Namun 
dalam kenyataannya, tidak semua anak didik dapat mencapai hasil belajar sesuai yang diharapkan. Kadang nilai pelajaran matematika mereka dibawah rata-rata bila dibandingkan dengan jenis pelajaran lainnya. Hal ini dapat disebabkan oleh beberapa faktor diantaranya baik faktor dalam diri atau pun dari luar diri siswa tersebut. Sebagai contoh faktor dalam diri yaitu kurangnya motivasi belajar siswa yang mengakibatkan kurangnya partisipasi aktif siswa dalam proses belajar mengajar, dan faktor dari luar yaitu adanya ketidaksesuaian model ataupun teknik pembelajaran yang digunakan dalam proses belajar mengajar (PBM) dengan kondisi siswa.

Hampir setiap guru matematika setuju akan pentingnya motivasi yang besar untuk mengajarkan matematika. Murid-murid, kecuali yang memang secara alami sudah senang terhadap matematika, perlu diberi rangsangan secara teknis dan cara pengajaran yang tepat agar senang terhadap matematika. Hanya dengan cara yang demikian kita dapat menghilangkan masalah terhadap matematika seperti kegelisahan terhadap matematika, yang merupakan masalah umum bertahun-tahun (Sobel \& Maletsky dalam Septianingsih, 2009:2). Untuk itu, secara terus-menerus dan bertahap guru mengusahakan mencari jalan dalam meningkatkan mutu pendidikan. Dalam berinteraksi antara siswa dengan guru, diharapkan guru dapat menjalankan peranannya sebagai pengajar dan pendidik. Dalam berinteraksi antara siswa dengan guru biasanya banyak menimbulkan masalah atau kurang terarah, hal ini dikarenakan guru kurang tepat dalam menggunakan pendekatan dalam pembelajaran. Sebagai suatu proses, pendidikan merupakan serangkaian kegiatan yang sistematis diarahkan terhadap perubahan tingkah laku siswa yang tercermin dalam pengetahuan, sikap dan tingkah laku yang berlangsung di lingkungan keluarga, sekolah dan masyarakat.

Proses pembelajaran khususnya pembelajaran matematika akan lebih efektif dan bermakna apabila siswa berpartisipasi aktif. Salah satu ciri kebermaknaan dalam proses belajar mengajar adalah adanya keterlibatan atau partisipasi siswa dalam proses belajar mengajar. Partisipasi merupakan suatu sikap berperan serta, ikut serta, keterlibatan, atau proses belajar bersama saling memahami, menganalisis, merencanakan dan melakukan tindakan (Hartono dalam Septianingsih, 2009:3). Peran aktif atau partisipasi siswa dalam mengikuti pembelajaran masih kurang. Kenyataan di sekolah menunjukan bahwa proses belajar mengajar matematika yang berlangsung di kelas sebenarnya telah melibatkan siswa, misalnya siswa mendengar guru menerangkan, membaca dan mencatat pelajaran yang diberikan. Tetapi sebagian besar siswa terlibat jarang mengajukan pertanyaan atau mengutaran pendapatnya walaupun guru telah berulang kali meminta agar siswa jika ada hal-hal yang kurang jelas, banyak siswa terlihat malas, tidak percaya diri mengerjakan soal-soal latihan dan baru akan mengerjakan setelah soal selesai dikerjakan oleh guru atau siswa lain yang berperan aktif. Pelajaran matematika tidak segera dikuasai dengan mendengarkan dan mencatat saja, masih perlu lagi partisipasi siswa dalam kegiatan lain seperti bertanya, mengerjakan latihan, mengerjakan PR, maju ke depan kelas, mengadakan diskusi, mengeluarkan ide atau gagasan, membangun pengetahuannya sendiri. Hal ini sesuai dengan pandangan kontruktivisme, menurut Semiawan (Sujiono, 2010:28) mengungkapkan bahwa siswa sebaiknya secara aktif membangun sendiri pengetahuannya. Pandangan konstruktivis tentang pembelajaran menyatakan siswa seyogianya diberi kesempatan agar menggunakan strategi sendiri dalam belajar secara sadar dan guru membimbing siswa ke tingkat pengetahuan yang lebih tinggi. Seorang guru harus mampu memfasilitasi siswanya dalam membangun pengetahuannya dengan cara menstimulasi terjadinya proses adaptasi. Thomas Staton (Puspitasari, 2009:3) menyatakan salah satu cara untuk menstimulasinya dengan mengajukan serangkaian pertanyaan yang tersusun secara sistematis yang dapat diajukan pada saat-saat yang tepat selama pembelajaran berlangsung.

Untuk mengantisipasi masalah tersebut agar tidak berkelanjutan, maka para guru terus berusaha menyusun dan menerapkan berbagai metode yang bervariasi. Salah satunya dengan menerapkan teknik probing dalam pembelajaran matematika yang dikolaborasikan dengan model pembelajaran kooperatif. 
JURNAL SAINTIFIK VOL.2 NO.1, JANUARI 2016

Isjoni (2010) berpendapat bahwa pembelajaran kooperatif adalah salah satu bentuk pembelajaran yang berdasarkan faham konstruktivis. Pembelajaran kooperatif merupakan strategi belajar dengan sejumlah siswa sebagai anggota kelompok kecil yang tingkat kemampuannya berbeda. Dalam menyelesaikan tugas kelompoknya, setiap siswa anggota kelompok harus saling bekerja sama dan saling membantu untuk memahami materi pelajaran. Dalam pembelajaran kooperatif, belajar dikatakan belum selesai jika salah satu teman dalam kelompok belum menguasai bahan pelajaran. Probing menurut bahasa adalah penyelidikan (Echol dan Shadily, 2005:448). Namun menurut Wijaya (Puspitasari, 2009:4) probing adalah suatu teknik pembelajaran dengan cara mengajukan satu seri pertanyaan untuk membimbing siswa menggunakan pengetahuan yang telah ada pada dirinya agar dapat membangun sendiri menjadi pengetahuan baru. Teknik probing adalah pembelajaran dengan cara guru menyajikan serangkaian pertanyaan yang sifatnya menuntun dan menggali sehingga terjadi proses berpikir yang mengaitkan pengetahuan siswa dan pengalamanya dengan pengetahuan baru yang sedang dipelajari. Selanjutnya siswa mengontruksi konsep-prinsip-aturan menjadi pengetahuan baru (Septianingsih, 2009:2).

Pengertian probing dalam pembelajaran di kelas didefinisikan sebagai suatu teknik membimbing dengan mengajukan satu seri pertanyaan pada seorang siswa. Teknik probing adalah suatu teknik dalam pembelajaran dengan cara mengajukan satu seri pertanyaan untuk membimbing pebelajar/siswa menggunakan pengetahuan yang telah ada pada dirinya guna memahami gejala atau keadaan yang sedang diamati sehingga terbentuk pengetahuan baru. Teknik probing diawali dengan menghadapkan siswa pada situasi baru berupa benda-benda nyata. Situasi baru itu membuat siswa mengalami pertentangan dengan pengetahuan yang sudah dimilikinya sehingga memberikan peluang kepada siswa untuk mengadakan asimilasi, disinilah probing (pembimbingan menggunakan satu seri pertanyaan) mulai diperlukan (Dahar, 1996:9).

Dengan teknik ini proses tanya jawab dilakukan dengan menunjukan siswa secara acak sehingga setiap siswa mau tidak mau harus berpartisipasi aktif, siswa tidak bisa menghindar dari proses pembelajaran, setiap saat ia bisa dilibatkan dalam proses tanya jawab. Kemungkinan akan terjadi suasana tegang, namun demikian bisa dibiasakan. Untuk mengurangi kondisi tersebut, guru hendaknya merangkai pertanyaan disertai dengan wajah ramah, suara menyejukkan, nada lembut. Ada canda, senyum, dan tertawa, sehingga suasana menjadi nyaman, menyenangkan, dan ceria. Jangan lupa bahwa jawaban siswa yang salah harus dihargai karena salah adalah cirinya dia sedang belajar, ia telah berpartisipasi (Septianingsih, 2009:2). Melalui probing seringkali diperoleh informasi yang jauh lebih penting, yang tidak mungkin diketahui tanpa usaha probing yang efektif. Tentu, guru memerlukan dukungan sistem, agar pada saat melaksanakan probing diperoleh hasil yang baik (Suyatno, 2008:1).

Dalam penelitian Wibowo (2010) "Penerapan Pembelajaran dengan Teknik Probing dalam Kelompok Kecil untuk meningkatkan Kemampuan Komunikasi pada Siswa" menujukkan hasil bahwa dengan penerapan teknik probing mampu merangsang dan meningkatkan kemampuan dan keberanian komunikasi siswa dalam mengontruksi pengetahuan-pengetahuan yang dipahaminya.

Berkaitan dengan masalah-masalah di atas, peneliti melakukan refleksi awal terhadap proses dan hasil pembelajaran matematika yang terjadi di SMP Negeri 26 Makassar. Setelah peneliti melakukan observasi pendahuluan dan wawancara dengan guru bidang studi matematika, ditemukan permasalahan antara lain: 1) guru masih dominan dalam pembelajaran, 2) partisipasi aktif siswa masih sangat kurang, 3) siswa terlihat malas dan kurang percaya diri untuk mengajukan pertanyaan kepada guru, 4) siswa tidak berani mengemukakan ide/ gagasan pada guru, 5) hanya sebagian kecil siswa yang mau maju ke depan kelas untuk mengerjakan soal maupun memberikan penjelasan kepada siswa lain. Kondisi ini berdampak pada pencapaian hasil belajar siswa yakni pada ujian mid semester genap, hasil belajar matematika siswa kelas VIII masih rendah, hanya 9 orang siswa $(23,68 \%)$ dari 38 orang siswa yang tuntas/kompeten dengan nilai rata-rata kelas 55,95, untuk itu perlu ditingkatkan karena banyak siswa belum mencapai standar KKM yang ditetapkan di sekolah tersebut, yaitu 65,00. 
Peneliti memilih teknik probing dalam proses pembelajaran sebagai teknik pembelajaran untuk mengajarkan materi kubus dan balok. Pemilihan pokok bahasan ini karena 3 alasan. Pertama, karena materi kubus dan balok tidak hanya diterapkan di sekolah saja tetapi materi ini erat kaitannya dengan lingkungan masyarakat dan lebih khusus lagi dalam lingkungan siswa sehari-hari. Kedua, pokok bahasan kubus dan balok merupakan lanjutan dari materi dasar bidang datar dalam pembelajaran matematika. Ketiga, kubus dan balok termasuk dalam ilmu geometri dimana, geometri sebagai salah satu cabang matematika yang sudah diajarkan sejak $\mathrm{SD}$, mempunyai posisi strategis untuk menumbuh kembangkan kemampuan nalar siswa dan dapat dipandang sebagai latihan untuk menata nalar/wawasan keruangan siswa. Namun keadaan di lapangan menunjukkan bahwa penguasaan materi geometri oleh siswa adalah sukar mengenali dan memahami bangun-bangun geometri. Hal ini dapat dilihat dari pencapaian nilai siswa yang telah diajarkan materi bangun ruang sisi datar yaitu kelas VIII pada tahun ajaran sebelumnya. Berdasarkan hasil ulangan harian yang diberikan kepada siswa bahwa hanya terdapat 5 siswa yang tuntas dari 34 siswa pada ulangan harian materi kubus dan balok.

Melalui Penelitian Tindakan Kelas diharapkan ada peningkatan hasil belajar siswa yang signifikan pada pembelajaran matematika di SMP Negeri 26 Makassar. Guru matematika sebagai mitra peneliti sangat mendukung upaya pencapaian kondisi tersebut. Berangkat dari pemikiran tersebut peneliti memilih "Penerapan Teknik Probing dalam Model Pembelajaran Kooperatif pada Pokok Bahasan Kubus dan Balok untuk Meningkatkan Hasil Belajar Matematika Siswa kelas VIII SMPN 26 Makassar".

\section{METODE PENELITIAN}

Penelitian ini adalah Penelitian Tindakan Kelas (Classroom Action Research) yang dilaksanakan selama dua siklus. Tindakan yang dilakukan adalah penggunaan teknik probing dalam pembelajaran matematika dengan tahapan-tahapan perencanaan, pelaksanaan tindakan, observasi, dan refleksi, menurut Mc Taggart (Kunandar, 2010:2).

Subjek penelitian ini adalah siswa kelas VIII 6 SMP Negeri 26 Makassar dengan jumlah siswa sebanyak 38 orang. Peneliti memilih kelas ini karena pencapaian hasil belajar siswa yakni pada ujian mid semester, hasil belajar matematika siswa kelas VIII $_{6}$ masih rendah, hanya 9 orang siswa $(23,68 \%)$ dari 38 orang siswa yang tuntas/kompeten dengan nilai rata-rata kelas 55,95 , untuk itu perlu ditingkatkan karena banyak siswa belum mencapai standar KKM yang ditetapkan di sekolah tersebut, yaitu 65,00. Faktor-faktor utama yang menjadi perhatian untuk diselidiki adalah: (1) Faktor Input, yaitu dengan melakukan observasi awal untuk mengetahui kondisi proses belajar mengajar di kelas $\mathrm{VIII}_{6}$ SMP Negeri 26 Makassar meliputi cara mengajar guru, cara belajar siswa, kemampuan awal siswa dalam belajar, (2) Faktor Proses, Dengan melihat aktivitas siswa selama pembelajaran berlangsung. Aktivitas siswa tersebut meliputi bagaimana siswa menjawab pertanyaan dan memberikan tanggapan atas pertanyaan guru, siswa yang mengajukan pertanyaan dan siswa yang dapat menemukan pengetahuan baru dari pertanyaan-pertanyaan guru tersebut. Dan aktivitas guru yakni dengan melihat bagaimana cara guru membawakan materi pelajaran dengan menerapkan teknik probing dalam model pembelajaran kooperatif pada proses pembelajaran, (3) Faktor Output, yaitu dengan melihat hasil belajar matematika siswa dan respon siswa terhadap pembelajaran matematika melalui penerapan teknik probing model pembelajaran kooperatif pada proses pembelajaran.

Rencana tindakan berupa intervensi kegiatan belajar mengajar di kelas dengan desain materi dan tugas tersendiri yang dilaksanakan selama 2 siklus dan masing-masing siklus terdiri dari 4 tahapan sebagai berikut:

\subsection{Siklus I}

2.5.1 Tahap Perencanaan ( planning )

Adapun kegiatan yang akan dilakukan dalam tahap perencanaan ini sebagai berikut: 1) Membuat perangkat pembelajaran untuk setiap pertemuan, yang meliputi: Rencana Pelaksanaan 
JURNAL SAINTIFIK VOL.2 NO.1, JANUARI 2016

Pembelajaran (RPP) dan Lembar Kerja Siswa (LKS). 2) Membuat lembar observasi untuk mengamati kondisi pembelajaran di kelas ketika pelaksanaan tindakan sedang berlangsung. 3) Membuat angket untuk mengetahui tanggapan siswa tentang penerapan teknik probing dalam model pembelajaran kooperatif pada proses pembelajaran. 4) Mendesain alat evaluasi untuk melihat kemampuan siswa dalam menyelesaikan soal-soal.

2.5.2 Pelaksanaan tindakan (action)

Melaksanakan skenario pembelajaran yang telah direncanakan yang berisi tentang tindakan yang akan ditetapkan yaitu menggunakan teknik probing dalam model pembelajaran kooperatif pada proses pembelajaran matematika. Adapun tindakan-tindakannya adalah sebagai berikut: 1) Penyajian materi pelajaran dimulai dengan guru menyampaikan tujuan pembelajaran dan memotivasi siswa untuk belajar sekaligus menyajikan informasi atau materi. 2) Mengorganisasi siswa dalam bentuk kelompok-kelompok, 3) Mengimplementasikan rencana pelaksanaan pembelajaran yang telah dibuat sebelumnya yang menggunakan teknik probing dalam proses pembelajaran. Adapun tahap-tahap pelaksanaanya adalah : Tahap I :

menghadapkan siswa pada situasi baru, misalnya dengan memperlihatkan gambar, benda atau situasi lainnya. Tahap II : : mengajukan pertanyaan sesuai dengan Tujuan Pembelajaran Khusus (TPK)/indikator kepada seluruh siswa. Tahap III : memberikan kesempatan kepada siswa untuk merumuskan jawaban atau melakukan diskusi kecil.Tahap IV : memberikan kesempatan kepada siswa untuk mengajukan pertanyaan jika ada hal yang kurang dimengerti dan membimbingnya. Tahap $V$ : menunjuk salah satu siswa untuk menjawab pertanyaan. Tahap $V I$ : jika jawaban siswa tepat maka guru meminta tanggapan siswa lain tentang jawaban tersebut. Jika siswa tersebut mengalami kemacetan menjawab dalam hal ini jawaban yang diberikan kurang tepat, tidak tepat atau diam, maka guru mengajukan pertanyaan-pertanyaan lain yang membimbing dan jawabannya merupakan petunjuk jalan penyelesaian jawaban.Tahap VII : mengajukan pertanyaan akhir kepada siswa untuk menunjukkan bahwa Tujuan pembelajaran khusus (TPK)/indikator tersebut benar-benar telah dipahami. 4) Memberikan tes untuk mengetahui hasil belajar terkait materi yang yang telah disajikan

\subsubsection{Observasi dan evaluasi (Observation and evaluation)}

Pada tahap ini dilaksanakan proses evaluasi terhadap pelaksanaan tindakan dengan menggunakan lembar observasi yang telah dibuat serta melaksanakan evaluasi.

\subsubsection{Refleksi (Reflection)}

Hasil yang diperoleh pada tahap observasi dan evaluasi, selanjutnya dikumpulkan dan dianalisis. Refleksi yang dimaksudkan adalah pengkajian terhadap keberhasilan atau kegagalan pencapaian tujuan sementara. Hasil analisis data yang dilaksanakan pada tahap ini akan dipergunakan sebagai acuan untuk menentukan tindakan pada siklus berikutnya dalam rangka pencapaian tujuan akhir. Untuk itu, refleksi dalam penelitian ini akan dilakukan setiap akhir tindakan dan setiap akhir siklus.

\subsection{Siklus II}

Pada Siklus II ini dilaksanakan selama empat kali pertemuan. Pada dasarnya langkahlangkah yang dilakukan dalam Siklus II ini telah memperoleh refleksi, selanjutnya dikembangkan dan dimodifikasi tahapan-tahapan yang ada pada siklus I dengan beberapa perbaikan dan penambahan sesuai dengan kenyataan yang ditemukan.

Adapun teknik pengumpulan data yang dilakukan adalah: (1) Data hasil belajar akan diambil dengan memberikan tes kepada siswa setiap akhir siklus. (2) Data tentang situasi belajar mengajar pada saat dilakukannya tindakan akan diambil dengan menggunakan lembar observasi. (3) Data tentang tanggapan siswa akan diperoleh dengan memberikan kesempatan kepada siswa untuk menuliskan tanggapan pada akhir siklus II. Data yang telah terkumpul selanjutnya akan dianalisis secara kuantitatif dan kualitatif. Data hasil observasi dan data tentang tanggapan siswa akan dianalisis secara kualitatif, sedangkan data mengenai hasil tes 
matematika siswa akan dianalisis secara kuantitatif dengan menggunakan statistika deskriptif yaitu skor rata-rata, persentase, nilai maksimum, nilai minimum dan standar deviasi yang dicapai siswa setiap siklus.

Skor standar yang umum digunakan adalah skala lima yaitu suatu pembagian tingkatan yang terbagi atas lima yaitu (Departemen Pendidikan dan Kebudayaan: 1994) :

- Untuk tingkat $85 \%$ - 100\% dikategorikan sangat tinggi

- Untuk tingkat $65 \%$ - $84 \%$ dikategorikan tinggi

- Untuk tingkat $55 \%$ - $64 \%$ dikategorikan sedang

- Untuk tingkat 35\% - 54\% dikategorikan rendah

- Untuk tingkat $0 \%$ - 34\% dikategorikan sangat rendah

Indikator keberhasilan penelitian tindakan kelas ini adalah: 1) Aktivitas siswa lebih meningkat selama mengikuti pembelajaran matematika misalnya meningkatnya jumlah siswa yang berani mengajukan pertanyaan kepada guru, siswa mampu mengkomunikasikan pengetahuannya untuk menjawab pertanyaan guru dan siswa mampu menanggapi jawaban teman dari kelompok lain. 2) Guru membawakan materi pelajaran dengan menggunakan teknik probing dalam model pembelajaran kooperatif dengan baik yaitu jika $60 \%$ dari jumlah siswa memberikan tanggapan yang bersifat positif terhadap penerapan teknik probing dalam model pembelajaran kooperatif pada proses pembelajaran. 3) Jika 85\% dari jumlah siswa memperoleh hasil belajar yang mencapai KKM Matematika yang telah ditetapkan di sekolah.

\section{HASIL DAN PEMBAHASAN}

Selama proses pembelajaran berlangsung dilakukan observasi terhadap pelaksanaan tindakan dengan menggunakan lembar observasi yang telah dipersiapkan dengan mencatat semua kejadian yang terjadi dalam pelaksanaan tindakan. Data hasil observasi dianalisis secara deskriptif kualitatif.

Analisis terhadap hasil-hasil observasi pelaksanaan pembelajaran dilakukan berdasarkan data-data observasi aktivitas siswa. Adapun hasil observasi Siklus I dan II dirangkup pada tabel berikut.

Tabel 1. Hasil Observasi aktivitas siswa melalui penerapan teknik probing dalam model pembelajaran kooperatif pada Siklus I dan II

\begin{tabular}{|c|c|c|c|c|c|c|c|c|c|c|c|}
\hline \multirow{3}{*}{ No } & \multirow{3}{*}{ Komponen yang Diamati } & \multicolumn{5}{|c|}{ Siklus I } & \multicolumn{5}{|c|}{ Siklus II } \\
\hline & & \multicolumn{4}{|c|}{ Pertemuan } & \multirow{2}{*}{$\begin{array}{l}\text { Persentase } \\
\quad(\%)\end{array}$} & \multicolumn{4}{|c|}{ Pertemuan } & \multirow{2}{*}{$\begin{array}{l}\text { Persentase } \\
\quad(\%)\end{array}$} \\
\hline & & 1 & 2 & 3 & 4 & & 5 & 6 & 7 & 8 & \\
\hline 1. & Siswa yang hadir & 36 & 36 & 36 & 36 & 94,74 & 38 & 38 & 36 & 37 & 98,03 \\
\hline 2. & Siswa yang memperhatikan & 16 & 20 & 24 & 28 & 61,11 & 28 & 29 & 30 & 31 & 79,19 \\
\hline 3. & penjelasan guru & 8 & 10 & 12 & 12 & 29,17 & 12 & 14 & 11 & 15 & 34,99 \\
\hline 4. & Siswa yang & 5 & 8 & 11 & 10 & 23,61 & 10 & 8 & 10 & 11 & 26,17 \\
\hline 5. & pertanyaan guru & 12 & 12 & 16 & 25 & 45,14 & 26 & 25 & 24 & 26 & 67,78 \\
\hline 6. & $\begin{array}{l}\text { Siswa yang mengajukan } \\
\text { pertanyaan } \\
\text { Siswa yang berpartisipasi aktif } \\
\text { dalam diskusi kelompok }\end{array}$ & 3 & 6 & 8 & 11 & 19,44 & 9 & 6 & 8 & 8 & 20,80 \\
\hline 7. & $\begin{array}{l}\text { Siswa mengerjakan soal di papan } \\
\text { tulis/mewakili kelompok untuk }\end{array}$ & 3 & 4 & 4 & 5 & 11,11 & 5 & 4 & 4 & 6 & 12,75 \\
\hline 8. & $\begin{array}{l}\text { memaparkan hasil diskusi } \\
\text { kelompoknya }\end{array}$ & 2 & 4 & 3 & 5 & 9,72 & 5 & 4 & 5 & 4 & 12,08 \\
\hline 9. & $\begin{array}{l}\text { Siswa yang menanggapi/ } \\
\text { menyampaikan ide/gagasanya }\end{array}$ & 4 & 10 & 17 & 20 & 35,42 & 23 & 28 & 28 & 30 & 73,15 \\
\hline
\end{tabular}


JURNAL SAINTIFIK VOL.2 NO.1, JANUARI 2016

\begin{tabular}{|c|c|c|c|c|c|c|c|c|c|c|c|}
\hline \multirow{3}{*}{ No } & \multirow{3}{*}{ Komponen yang Diamati } & \multicolumn{5}{|c|}{$\begin{array}{l}\text { Siklus I } \\
\end{array}$} & \multicolumn{5}{|c|}{ Siklus II } \\
\hline & & \multicolumn{4}{|c|}{ Pertemuan } & \multirow{2}{*}{$\begin{array}{c}\text { Persentase } \\
(\%)\end{array}$} & \multicolumn{4}{|c|}{ Pertemuan } & \multirow{2}{*}{$\begin{array}{c}\text { Persentase } \\
(\%)\end{array}$} \\
\hline & & 1 & 2 & 3 & 4 & & 5 & 6 & 7 & 8 & \\
\hline & $\begin{array}{l}\text { Siswa yang terlibat dalam } \\
\text { membuat kesimpulan } \\
\text { Siswa yang bersemangat dan } \\
\text { tertarik untuk mempelajari } \\
\text { matematika dengan teknik } \\
\text { probing }\end{array}$ & & & & & & & & & & \\
\hline 10 & $\begin{array}{l}\text { Siswa yang melakukan aktivitas } \\
\text { lain yang tidak berkaitan dengan } \\
\text { PBM }\end{array}$ & 20 & 16 & 13 & 8 & 39,58 & 10 & 9 & 6 & 8 & 22,15 \\
\hline
\end{tabular}

Tes hasil belajar pada siklus ini dilaksanakan pada akhir siklus.Tes pada Siklus I dilaksanakan setelah selesai penyajian sub pokok bahasan sifat-sifat kubus dan balok serta bagian-bagiannya.Tes pada Siklus II dilaksanakan setelah selesai penyajian sub pokok luas permukaan dan volume kubus dan balok. Adapun rangkuman statistik skor hasil belajar matematika siswa pada Siklus I dan II adalah sebagai berikut:

Adapun Deskripsi hasil belajar Matematika pada Siklus I dan II ini dapat dilihat pada tabel berikut :

Tabel 2. Statistik skor hasil belajar matematika siswa melalui penerapan teknik probing dalam model pembelajaran kooperatif pada Siklus I dan II

\begin{tabular}{|c|c|c|c|}
\hline \multicolumn{2}{|c|}{ Siklus I } & \multicolumn{2}{|c|}{ Siklus II } \\
\hline Statistik & Nilai Statistik & Statistik & Nilai Statistik \\
\hline Subjek & 38 & Subjek & 38 \\
\hline Skor Ideal & 100 & Skor Ideal & 100 \\
\hline Skor & 90,00 & Skor Tertinggi & 95,00 \\
\hline Tertinggi & & Skor Terendah & 58,00 \\
\hline Skor & 50,00 & Rentang Skor & 37,00 \\
\hline Terendah & & Rata-rata Skor & 79,39 \\
\hline Rentang Skor & 40,00 & Standar Deviasi & 9,287 \\
\hline Rata-rata Skor & 71,79 & & \\
\hline Standar & 9,352 & & \\
\hline Deviasi & & & \\
\hline
\end{tabular}

Apabila skor hasil belajar siswa pada siklus I dan II dikelompokkan ke dalam lima kategori, maka diperoleh distribusi frekuensi skor yang ditunjukkan pada tabelberikut:

Tabel 3. Distribusi Frekuensi dan Persentase Skor hasil belajar matematika siswa melalui penerapan teknik probing dalam model pembelajaran kooperatif pada Siklus I dan II

\begin{tabular}{clccccc}
\hline \multirow{2}{*}{ Skor } & \multirow{2}{*}{ Kategori } & \multicolumn{2}{c}{ Siklus I } & & \multicolumn{2}{c}{ Siklus II } \\
\cline { 3 - 4 } \cline { 6 - 7 } & & Frekuensi & $\begin{array}{c}\text { Persentase } \\
(\%)\end{array}$ & & Frekuensi & $\begin{array}{c}\text { Persentase } \\
(\%)\end{array}$ \\
\hline $0-34$ & Sangat rendah & 0 & 0 & & 0 & 0 \\
$35-54$ & Rendah & 3 & 7,89 & & 0 & 0 \\
$55-64$ & Sedang & 5 & 13,15 & & 2 & 5,26 \\
\hline
\end{tabular}


JURNAL SAINTIFIK VOL.2 NO.1, JANUARI 2016

\begin{tabular}{|c|c|c|c|c|c|}
\hline $65-84$ & Tinggi & 28 & 73,68 & 19 & 50,00 \\
\hline $85-100$ & Sangat Tinggi & 2 & 5,26 & 17 & 44,74 \\
\hline \multicolumn{2}{|c|}{ Jumlah } & 38 & 100 & 38 & 100 \\
\hline
\end{tabular}

Salah satu indikator keberhasilan dalam penelitian ini adalah jika $85 \%$ dari jumlah siswa memperoleh hasil belajar yang mencapai KKM Matematika yang telah ditetapkan di SMP Negeri 26 Makassar yaitu 65,00. Deskripsi ketuntasan belajar matematika pada siklus I dan II, disajikan dalam tabel berikut:

Tabel 4. Deskripsi Ketuntasan Belajar Matematika Siswa melalui penerapan teknik probing dalam model pembelajaran kooperatif pada Siklus I

\begin{tabular}{|c|c|c|c|c|c|}
\hline \multirow[b]{2}{*}{ Skor } & \multirow[b]{2}{*}{ Kategori } & \multicolumn{2}{|r|}{ Siklus I } & \multicolumn{2}{|r|}{ Siklus II } \\
\hline & & Frekuensi & $\begin{array}{l}\text { Persentase } \\
(\%)\end{array}$ & Frekuensi & $\begin{array}{l}\text { Persentase } \\
(\%)\end{array}$ \\
\hline$<65$ & Tidak Tuntas & & 1,05 & & ,26 \\
\hline$\geq 65$ & Tuntas & 0 & 8,95 & 6 & 4,74 \\
\hline & Jumlah & 4 & 00,00 & 8 & 00,00 \\
\hline
\end{tabular}

Siklus I dilaksanakan selama 4 kali pertemuan. Selama siklus I ini berlangsung, diterapkan teknik probing dalam proses belajar mengajar matematika. Pada akhir siklus I diadakan tes hasil belajar setelah penyajian beberapa subpokok bahasan Kubus dan Balok selesai. Analisis deskriptif terhadap hasil belajar matematika siswa pada tabel 2, menunjukkan bahwa pada siklus I skor tertinggi 90, skor terendah 50, skor rata-rata 71,79. Jika hasil belajar matematika tersebut di kelompokkan ke dalam lima kategori, maka dapat diperoleh distribusi frekuensi skor menunjukkan bahwa tidak ada satupun siswa yang berada dalam kategori sangat rendah atau $0 \%$, dalam kategori rendah sebanyak 3 siswa atau 7,89\%, dalam kategori sedang sebanyak 5 siswa atau 13,15\%, dalam kategori tinggi sebanyak 28 siswa atau 73,68\%, dan dalam kategori sangat tinggi sebanyak 2 siswa atau 5,26\%. Jadi banyaknya siswa yang hasil belajarnya berada pada kategori tinggi dan sangat tinggi yaitu 30 siswa atau sebesar 78,95\%. Dan setelah penerapan teknik probing dalam proses belajar mengajar pada siklus I jumlah siswa kelas VIII $_{6}$ SMP Negeri 26 Makassar yang hasil belajarnya mencapai KKM matematika yang telah ditetapkan di sekolah berjumlah 30 siswa atau 78,95\%.

Siklus II dilaksanakan selama 4 kali pertemuan. Selama siklus II ini berlangsung diterapkan teknik probing dalam proses belajar mengajar matematika, tetapi diadakan beberapa perubahan tindakan berdasarkan hasil refleksi pada siklus I. Pada akhir siklus II diadakan tes hasil belajar. Analisis deskriptif terhadap hasil belajar matematika siswa pada tabel 2, menunjukkan bahwa pada siklus II skor tertinggi 95 skor terendah 58 skor rata-rata 79,39. Jika hasil belajar matematika tersebut di kelompokkan ke dalam lima kategori, maka dapat diperoleh distribusi frekuensi skor yang disajikan menunjukkan bahwa tidak ada siswa yang berada dalam kategori sangat rendah dan rendah atau $0 \%$, pada kategori sedang terdapat 2 siswa atau $5,26 \%$, dalam kategori tinggi sebanyak 19 orang atau 50,00\%, dan dalam kategori sangat tinggi sebanyak 17 orang atau 44,74\%. Dan setelah diadakan beberapa perubahan tindakan pada siklus 
II berdasarkan hasil refleksi pada siklus I banyaknya siswa kelas VIII 6 SMP Negeri 26 Makassar yang hasil belajarnya mencapai KKM matematika yang telah ditetapkan di sekolah adalah 36 siswa atau $94,74 \%$.

Dari uraian di atas menunjukkan adanya peningkatan hasil belajar matematika siswa kelas VIII 6 SMP Negeri 26 Makassar dari sebelum dan setelah diterapkan teknik probing dalam proses belajar mengajarnya. Hal ini terlihat pada tabel 4, dari pencapain hasil belajar sebelum diterapkan tindakan yaitu hanya 9 orang siswa $(23,68 \%)$ dari 38 orang siswa yang tuntas/kompeten dengan nilai rata-rata kelas 55,95 meningkat setelah diterapkan tindakan menjadi 36 orang siswa $(94,74 \%)$ yang telah tuntas belajar dengan nilai rata rata 79,39 . Ini berarti ketuntasan belajar telah tercapai secara klasikal karena jumlah siswa yang tuntas sudah

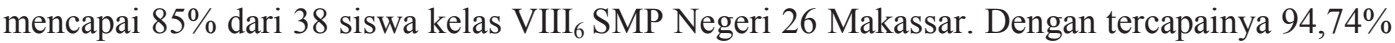
dari banyaknya siswa yang hasil belajarnya memenuhi KKM matematika maka salah satu indikator keberhasilan dalam penelitian ini telah terpenuhi.

Disamping terjadinya peningkatan hasil belajar matematika selama berlangsungnya penelitian dari sebelum diterapkan tindakan, siklus I sampai siklus II, tercatat sejumlah perubahan yang terjadi pada sikap siswa. Perubahan tersebut merupakan data kualitatif yang diperoleh dari lembar observasi pada setiap pertemuan yang dicatat oleh observer selama penelitian (terlihat pada tabel 1).

Perubahan-perubahan yang dimaksud adalah sebagai berikut:

1. Persentase kehadiran siswa semakin meningkat dari siklus I yaitu $94,74 \%$ menjadi $98,03 \%$ pada siklus II. Ini menandakan bahwa penerapan teknik probing dalam pembelajaran matematika dapat meningkatkan motivasi siswa untuk mengikuti pelajaran.

2. Siswa yang memperhatikan penjelasan guru pada siklus I yaitu $61,11 \%$ meningkat menjadi $79,19 \%$ pada siklus II. Ini menandakan bahwa perhatian siswa terhadap pelajaran metematika meningkat dan rasa keingintahuan memahami materi juga meningkat. Dan hal ini tidak nampak dari hasil observasi awal sebelum diterapkan teknik probing.

3. Keaktifan dan keberanian siswa juga terlihat dari persentase siswa menjawab pertanyaan dari guru, dimana siswa mulai berlomba-lomba menaikkan tangan untuk menjawab pertanyaan dari guru. Persentase siswa yang menjawab pertnyaan guru pada siklus I sebesar $29,17 \%$ meningkat menjadi $34,99 \%$ pada siklus II.

4. Responsif siswa dalam proses belajar mengajar semakin meningkat, terlihat dari siswa yang bertanya materi pelajaran yang belum dimengerti sebesar $23,61 \%$ pada siklus I meningkat menjadi $26,17 \%$ pada siklus II. Hal ini menandakan sudah adanya rasa percaya diri siswa dan keingintahuan siswa terhadap materi yang diajarkan. Tidak lagi siswa terlihat malas dan kurang percaya diri untuk mengajukan pertanyaan seperti yang nampak pada hasil observasi awal.

5. Siswa yang berpartisipasi aktif dalam diskusi kelompok jumlahnya semakin meningkat dari siklus I yaitu 45,14\% menjadi $67,78 \%$ pada siklus II. Hal ini menunjukkan meningkatnya kerjasama siswa dalam diskusi kelompok, dan tidak lagi hanya mengandalkan teman yang dianggapnya pintar karena semua ingin tahu.

6. Keberanian siswa menyelesaikan soal di papan tulis/mewakili kelompoknya untuk memaparkan hasil diskusi juga meningkat dari siklus I yaitu $19,44 \%$ menjadi $20,80 \%$ pada siklus II. Mereka berani bertanggungjawab terhadap hasil diskusi kelompoknya.

7. Siswa yang menanggapi/menyampaikan ide/gagasannya pada siklus I yaitu $11,11 \%$ meningkat menjadi $12,75 \%$ pada siklus II. Ini menunjukkan bahwa kepercayaan diri dan fokus siswa terhadap pelajaran matematika meningkat. Siswa semakin responsif terhadap berlangsungnya proses belajar mengajar.

8. Siswa yang terlibat dalam membuat kesimpulan materi yang telah diajarkan meningkat pula dari siklus I sebesar 9,72\% menjadi $12,08 \%$ pada siklus II. Mereka beramai ramai menawarkan diri untuk diberi kesempatan dalam menarik kesimpulan. Ketika mereka dapat menyimpulkan materi pelajaran pada akhir jam pelajaran, berarti perhatian siswa terfokus pada materi yang dipelajari selama jam pelajaran berlangsung. 
9. Meningkatnya persentase siswa yang bersemangat dan tertarik untuk mempelajari matematika dengan teknik probing dari siklus I yaitu $35,42 \%$ menjadi $73,15 \%$ pada siklus II. Hal ini menunjukkan sudah banyak siswa yang senang dengan penerapan teknik probing dalam pembalajaran matematika. Dan penelitian ini pun dapat dikatakan berhasil.

10. Menurunnya persentase siswa yang melakukan aktivitas lain pada saat proses belajar mengajar berlangsung dari siklus I 39,58\% menjadi 22,15\% pada siklus II.

Pada akhir siklus II peneliti memberikan pertanyaan kepada siswa yaitu berupa tanggapan siswa mengenai pembelajaran matematika serta proses belajar mengajar yang dilakukan selama penelitian berlangsung yaitu menerapkan teknik probing dalam proses belajar mengajar. Dari hasil data respon siswa dapat dilihat, secara klasikal, respon positif siswa terhadap penelitian ini adalah mencapai $73,31 \%$ dari 37 siswa yang hadir. Siswa-siswa tersebut juga berkomentar bahwa mereka senang dan bersemangat belajar dengan menggunakan teknik probing, karena guru selalu memberikan kesempatan kepada siswa untuk bertanya, menjawab pertanyaan, menanggapi sehingga mereka lebih berani untuk mengkomunikasikan pengetahuannya. Selain itu dengan penerapan teknik probing tersebut juga lebih meningkatkan pemahaman siswa karena guru selalu membimbing siswa jika ada hal yang kurang dipahami oleh siswa. Namun, ada juga sebagian kecil siswa merasa tidak senang belajar dengan penerapan teknik probing ini dengan alasan takut ditunjuk oleh guru dan malu kepada teman jika tidak bisa menjawab pertanyaan dari guru. Tapi terlepas dari semua itu, secara umum siswa lebih termotivasi untuk belajar matematika jika menggunakan teknik probing dalam proses belajar mengajar. Dalam hal ini berarti guru telah berhasil membawakan materi dengan menerapkan teknik probing dalam proses belajar mengajar.

Mereka menganggapi bahwa pembelajaran dengan menggunakan teknik probing sangat menarik, selain mengajar mereka untuk lebih percaya diri dalam memaparkan pengetahuannya, juga memacu semangat mereka untuk belajar lebih tekun sehingga mereka selalu siap menjawab pertanyaan dari guru. Selain itu, siswa juga tertarik dengan penyajian LKS yang terkesan sangat membimbing siswa dalam penyelesaiannya sehingga sangat mudah untuk diselesaikan. Terlihat bahwa hampir seluruh siswa memberikan tanggapan positif pada penerapan teknik probing dalam pembelajaran sehingga dapat dikatakan bahwa salah satu indikator keberhasilan yang ada telah terpenuhi yaitu jika $60 \%$ dari jumlah siswa memberikan tanggapan yang bersifat positif terhadap penerapan teknik probing dalam proses belajar mengajar.

\section{KESIMPULAN}

Berdasarkan hasil penelitian yang berlangsung selama dua siklus, dapat disimpulkan sebagai berikut:

1. Aktivitas siswa dalam proses pembelajaran matematika ketika guru menerapkan teknik probing dalam model pembelajaran kooperatif mengalami peningkatan dalam hal:

a. Motivasi, perhatian dan partisipasi aktif siswa dalam mengikuti proses belajar matematika.

b. Keberanian dan rasa percaya diri siswa mengajukan pertanyaan kepada guru, menjawab pertanyaan guru, menanggapi dan mengkomunikasikan pengetahuannya serta menarik kesimpulan.

c. Partisipasi aktif siswa dalam diskusi kelompok.

2. Penerapan teknik probing dalam model pembelajaran kooperatif dapat meningkatkan hasil belajar siswa kelas VIII 6 SMP Negeri 26 Makassar yaitu:

a. Skor rata-rata kemampuan awal siswa mencapai 55,95 dan banyaknya siswa yang hasil belajarnya mencapai KKM adalah 9 siswa atau 23,68\%.

b. Skor rata-rata hasil belajar siswa pada siklus I mencapai 71,79 dan jumlah siswa yang hasil belajarnya mencapai KKM matematika sebanyak 30 siswa atau 78,95\%. 
JURNAL SAINTIFIK VOL.2 NO.1, JANUARI 2016

c. Skor rata-rata hasil belajar siswa pada siklus II mencapai 79,39 dan jumlah siswa yang hasil belajarnya mencapai KKM matematika sebanyak 36 siswa atau 94,74\%.

3. Jumlah siswa yang mencapai KKM matematika pada siklus II $\geq 85 \%$ dari jumlah siswa yaitu sebanyak 36 siswa atau $94,74 \%$

4. Hampir seluruh siswa memberikan respon positif terhadap penerapan teknik probing dalam model pembelajaran kooperatif.

\section{DAFTAR PUSTAKA}

Dahar, Ratna Wilis. 1996. Teori-teori Belajar. Bandung : Erlangga

Departemen Pendidikan dan Kebudayaan. 1994. Kurikulum Pendidikan Dasar GBPP Matematika SLTP. Jakarta

Echols dan Shadily. 2005. Kamus Inggris-Indonesia. Jakarta : Gramedia

Hamalik, Oemar. 2004. Proses Belajar Mengajar. Bumi Aksara : Jakarta

Isjoni. 2010. Cooperative Learning. Bandung: Alfabeta

Kunandar. 2010. Penelitian Tindakan Kelas. Jakarta: Rajawali Pers.

Krismanto, Al. 2003. Beberapa Teknik, Model dan Strategi dalam Pembelajaran Matematika. Yogyakarta : Widyaswara PPPG Matematika

Muhkal, Mappaita. 2008. Materi Kuliah Strategi Belajar Mengajar Matematika. Makassar: FMIPA Universitas Negeri Makassar

Puspitasari, Nitta. 2009. Efektifitas Belajar Matematika dengan Teknik Probing. Diakses pada tanggal 18 Januari 2011.

Septianingsih, Isnaini. 2009. Upaya Peningkatan Partisipasi Belajar Siswa Melalui Model Pembelajaran Probing-Prompting di SMPN 3 Boyolali. Skripsi : Universitas Muhammadiyah Surakarta.

Soedjadi. 2000. Kiat Pendidikan Matematka di Indonesia. Konstatasi Keadaan Masa Kini Menuju Harapan Masa Depan. Dikrektorat Jenderal Pendidikan Tinggi. Departemen Pendidikan Nasional.

Sujiono, Bambang dan Nurani, Yuliani. 2010. Bermain Kreatif Berbasis Kecerdasan Jamak. Jakarta : PT. Indeks

Suryabrata, Sumadi. 2002. Psikologi Pendidikan. Jakarta : Rajawali Press.

Suyatno. 2008. Teknik Probing untuk Menguatkan Kapasitas Siswa. Di akses pada tanggal 10 Januari 2011

Suyitno, Amin. 2004. Dasar-dasar dan Proses Pembelajaran Matematika. Surabaya: Usaha Nasional.

Uno, Hamzah B. 2006. Perencanaan Pembelajaran. Jakarta: PT. Bumi Aksara.

Wibowo, Anggit. 2010. Penerapan Pembelajaran dengan Teknik Probing dalam Kelompok Kecil untuk meningkatkan Kemampuan Komunikasi pada Siswa. Skripsi : Universitas Muhammadiyah Surakarta. 